\title{
Antimicrobial Effect of Calcium Hydroxide Combined with Electrolyzed Superoxidized Solution at Neutral pH on Enterococcus faecalis Growth
}

\author{
Héctor Armando Jimenez-Gonzalez, ${ }^{1}$ María Argelia Akemi Nakagoshi-Cepeda, ${ }^{1}$ \\ Sergio Eduardo Nakagoshi-Cepeda ${ }^{\circ},{ }^{1}$ Víctor Hugo Urrutia-Baca ${ }^{\circ},{ }^{2}$ \\ Myriam Angélica De La Garza-Ramos $\mathbb{\complement},{ }^{1,3}$ Juan Manuel Solis-Soto $\mathbb{}^{1}$, \\ Ricardo Gomez-Flores $\mathbb{D}^{2},{ }^{2}$ and Patricia Tamez-Guerra $\mathbb{D}^{2}$ \\ ${ }^{1}$ Universidad Autónoma de Nuevo León, Facultad de Odontología, Av. Dr. Eduardo Aguirre Pequeño, Mitras Centro, Monterrey, \\ Nuevo León, C.P. 64460, Mexico \\ ${ }^{2}$ Universidad Autónoma de Nuevo León, Facultad de Ciencias Biológicas, Departamento de Microbiología e Inmunología, \\ Laboratorio de Inmunología y Virología, Ciudad Universitaria, San Nicolás de los Garza, Nuevo León, CP 66451, Mexico \\ ${ }^{3}$ Centro de Investigación y Desarrollo en Ciencias de la Salud, Unidad de Odontología Integral y Especialidades, Av. Dr. Aguirre \\ Pequeño y Silao S/N, Mitras Centro, Monterrey, Nuevo León, CP 64460, Mexico
}

Correspondence should be addressed to Víctor Hugo Urrutia-Baca; vurrutia1990@gmail.com
and Myriam Angélica De La Garza-Ramos; myriam.garzarm@uanl.edu.mx

Received 16 July 2021; Accepted 22 October 2021; Published 9 November 2021

Academic Editor: Yeliz Guven

Copyright (c) 2021 Héctor Armando Jimenez-Gonzalez et al. This is an open access article distributed under the Creative Commons Attribution License, which permits unrestricted use, distribution, and reproduction in any medium, provided the original work is properly cited.

\begin{abstract}
Objective. To evaluate the effect of the combination of calcium hydroxide $\left(\mathrm{Ca}(\mathrm{OH})_{2}\right)$ and a novel electrolyzed superoxidized solution at neutral pH, known as $\mathrm{OxOral}^{\circledR}$ on Enterococcus faecalis growth in root canals. Methods. Sixty human teeth were used, from which root canals were infected and randomly divided into the following treatment groups: saline solution, saline solution plus $\mathrm{Ca}(\mathrm{OH})_{2}$, $\mathrm{OxOral}^{\circledR}$, and $\mathrm{OxOral}{ }^{\circledR}$ plus $\mathrm{Ca}(\mathrm{OH})_{2}$. Results. A permanent reduction in bacterial growth was observed at days $1,6,12$, and 18 after OxOral ${ }^{\circledR}$ plus $\mathrm{Ca}(\mathrm{OH})_{2}$ treatment from $4.4 \pm 0.074 \log _{10} \mathrm{CFU} / \mathrm{mL}$ to $0.0 \pm 0.001 \log _{10} \mathrm{CFU} / \mathrm{mL}$. In addition, alkaline conditions maintenance was observed from application time $(\mathrm{pH}=12.2 \pm 0.033)$ to $18 \mathrm{~d}$ posttreatment $(\mathrm{pH}=12.6 \pm 0.083)$. Conclusion. The combination of $\mathrm{OxOral}^{\circledR}$ and $\mathrm{Ca}(\mathrm{OH})_{2}$ provides an alkaline $\mathrm{pH}$ and inhibits E. faecalis growth into the root canals. Our study opens the possibility for further research on the use of OxOral ${ }^{\circledR}$ in endodontic therapy.
\end{abstract}

\section{Introduction}

Untreated dental caries, crown, or root fractures of the tooth, conservative dental treatments that have not been properly applied, and exposure of pulp tissue to chemical agents or dental materials may lead to inflammation of the dental pulp tissue, known as pulpitis. Its progression leads to an irreversible condition, where the inflammation spreads to the tooth apices, periodontium, dentinal tubules, and blood vessels [1].

The endodontic treatment is commonly recommended, when there is irreversible pulpitis or pulp necrosis. Therapy consists of the total removal of the dental pulp and the three-dimensional sealing of the root canal to restore the function of the teeth within the masticatory apparatus $[2,3]$. During this treatment, the root canal is provisionally sealed with calcium hydroxide $\left(\mathrm{Ca}(\mathrm{OH})_{2}\right)$, which may be dissolved in saline solution or anesthesia, to keep clean and aseptic [3-5]. $\mathrm{Ca}(\mathrm{OH})_{2}$ is an odorless white powder obtained by calcination of calcium carbonate and its transformation into calcium oxide, which possesses a molecular weight of $74.08 \mathrm{~g} / \mathrm{mol}$, low solubility in water with a $\mathrm{pH}=12.5-12.8$, and is insoluble in alcohol. Many studies have demonstrated the properties 
of $\mathrm{Ca}(\mathrm{OH})_{2}$-based sealants, such as physical properties, biocompatibility, leaks, adhesion, antibacterial, and periapical healing effects $[6,7]$. The two most important reasons for using $\mathrm{Ca}(\mathrm{OH})_{2}$ in a dressing or intracanal medication are stimulation of the periapical tissues to maintain health and promotion of healing and its antimicrobial effects. Although the exact mechanisms are unknown, the following ones have been proposed: (a) $\mathrm{Ca}(\mathrm{OH})_{2}$ is antibacterial depending on the availability of free hydroxyl ions that encourages repair and active calcification [8-10]. Furthermore, it has been suggested that it acts indirectly by obliterating the root canal space, thus limiting the use of nutrients by the microorganisms lodged in the dentin [11], (b) ?added value="t"?> he alkaline $\mathrm{pH}$ neutralizes lactic acid from osteoclasts and prevents dissolution of mineralized components of teeth and also activates alkaline phosphatase and calcium-dependent adenosine triphosphatase reaction leading to hard tissue formation [12, 13], (c) it denatures proteins found in the root canal and makes them less toxic,and (d) it diffuses through dentinal tubules and may communicate with the periodontal ligament space to arrest external root resorption and accelerate healing $[12,13]$.

Despite its advantages, $\mathrm{Ca}(\mathrm{OH})_{2}$ endodontic treatments failure in teeth has been reported. Enterococcus faecalis has been reported as the bacterial microorganism responsible for the failure of endodontic therapies [14]. Enterococcus faecaliscolonizes inside dentinal tubules up to 300 microns, a site that is difficult to access for the action of $\mathrm{Ca}(\mathrm{OH})_{2}$, affecting its effectiveness in endodontic therapy $[15,16]$. Combining $\mathrm{Ca}(\mathrm{OH})_{2}$ with an appropriate solvent may increase its solubility, antimicrobial activity, and access to complex root canal sites. The solvent used for $\mathrm{Ca}(\mathrm{OH})_{2}$ influences both the physical and chemical properties of the material, including its viscosity and ion release pattern. A range of water-based materials has traditionally been used but there are alternative vehicles [17]. This study proposes using electrolyzed superoxidation solution (ESS) with neutral $\mathrm{pH}$ as the $\mathrm{Ca}(\mathrm{OH})_{2}$ solvent for the endodontic treatment. ESS has a neutral $\mathrm{pH}(6.4-7.5)$ and is produced from the electrolysis of sodium chloride $(\mathrm{NaCl})$ solution in an electrolytic cell where a diaphragm (partition or membrane) separates the anode and the cathode. Cations are drawn towards the electrode negative, where they receive electrons, forming a negatively charged antioxidant solution (alkaline solution). At the positive electrode, anions are attracted, which give up their additional electrons to create a positively charged oxidant solution (acid solution) [18]. For ESS formation, part of an antioxidant solution formed is channeled back into the anode chamber, thus increasing the content of hypochlorite ions $\left(\mathrm{OCl}^{-}\right)$. The reintroduction of the alkaline solution back into the acidic solution allows adjusting the $\mathrm{pH}$ up to neutral. Therefore, ESS is mainly composed of hypochlorous acid $(\mathrm{HOCl}), \mathrm{OCl}^{-}$, chlorine $\left(\mathrm{Cl}^{-}\right)$, and sodium hypochlorite $(\mathrm{NaOCl})$. Electrolysis may produce $\mathrm{H}^{+}$and $\mathrm{OH}$ ions, $\mathrm{H}$ and $\mathrm{OH}$ radicals, $\mathrm{H}_{2}, \mathrm{O}_{2}$, $\mathrm{HO}_{2}$, and $\mathrm{O}_{3}$ due to redox reactions. As a result, hydrogen and ozone gas are released, and a percentage of hydroxides remains in the solution in various forms, including but not limited to hydrogen peroxide $\left(\mathrm{H}_{2} \mathrm{O}_{2}\right)[19,20]$.
ESS has become a new alternative in tissue asepsis in different areas of medicine and the food industry for its high antimicrobial activity, stability, and safety [21, 22]. Some reports suggest that the presence of $\mathrm{Cl}^{-}$and a high concentration of oxidation-reduction potential (ORP) are responsible for the antimicrobial activity of ESS. However, other studies suggest that $\mathrm{HOCl}$ is the most active of compounds $[23,24]$.

A significant antimicrobial activity of ESS in removing biofilms from E. faecalis in root canals has been previously reported [25-29]. The aim of the present study was to evaluate the antimicrobial effect of combining $\mathrm{Ca}(\mathrm{OH})_{2}$ with an ESS with neutral $\mathrm{pH}$ called OxOral ${ }^{\circledR}$, in E. faecalis-infected root canals.

\section{Materials and Methods}

2.1. E. faecalis culture conditions. One cryovial containing E. faecalis (ATCC ${ }^{\circledR} 29212^{\mathrm{TM}}$ ) cells was rapidly thawed in a prewarmed $37^{\circ} \mathrm{C}$ water, and cells were placed into $100 \mathrm{~mL}$ brain heart infusion broth (BHI; Oxoid Limited, Hampshire, UK) supplemented with $5 \mu \mathrm{g} / \mathrm{mL}$ hemin and $0.5 \mu \mathrm{g} / \mathrm{mL}$ menadione at $0.5 \mathrm{McF}$ arland. The culture was incubated at $37{ }^{\circ} \mathrm{C}$ for $24 \mathrm{~h}$ under anaerobic conditions. Afterwards, $1 \mathrm{~mL}$ of the preculture of E. faecalis was collected, placed in $100 \mathrm{~mL}$ of BHI-supplemented broth, and incubated until reaching the exponential, logarithmic phase.

2.2. Instrumentation and Preparation of Teeth. Sixty human maxillary $2^{\text {nd }}$ premolar teeth were obtained from human volunteers of the Endodontic Postgraduate Program of the School of Dentistry at the Autonomous University of Nuevo Leon. The study was conducted following the Declaration of Helsinki, the Institutional Ethics Committee approved the protocol (SPSI-01613/00249), and informed consent was obtained from each volunteer. The dental crowns were sectioned with a diamond disc and press. The working length was determined with a \#15 dental file (K-Flex) of $25 \mathrm{~mm}$; $1 \mathrm{~mm}$ was subtracted from its exit from the apical foramen. Instrumentation began with Triple-Flex Files Stainless Steel files (SybronEndo, Ormex, Yucatan, Mexico) up to file \#40 using $5.2 \% \mathrm{NaOCl}$ as an irrigating agent between each file change to maintain conduit permeability.

The apical region of each tooth was sealed with composite resin and externally with a layer of nail varnish, excluding the cervical opening, which was enlarged with Gates GLID$\mathrm{DEN}$ files to be later autoclaved at $121^{\circ} \mathrm{C}$ for $15 \mathrm{~min}$ in $1.5 \mathrm{~mL}$ tubes. All root portions and materials used (cotton pellets, Eppendorf tubes, instruments, files, syringes, rotary drills, diamond disc, and serrated dissection forceps) were autoclaved.

2.3. Contamination and Treatment of Root Canals. Each root canal was inoculated with $15 \mu \mathrm{L}$ of E. faecalis with a bacterial concentration of $5 \log _{10} \mathrm{CFU} / \mathrm{mL}$ and incubated in an anaerobic atmosphere at $37^{\circ} \mathrm{C}$ for $21 \mathrm{~d}$ to achieve the formation of E. faecalis biofilms within the root canal, after which $10 \mu \mathrm{l}$ of supplemented BHI broth were added every two days to avoid teeth dehydration and promote bacterial growth. 
After incubation, 12 samples were randomly selected and plated on BHI agar to verify contamination of the root canals by CFU counting.

Sixty root canals were randomly divided into four groups, and $10 \mu \mathrm{L}$ of the treatment was applied within the root canal based on the following treatment groups: group 1, $0.9 \% \mathrm{NaCl}$; group 2, $0.9 \% \mathrm{NaCl}$ plus $\mathrm{Ca}(\mathrm{OH})_{2}$ paste; group 3, OxOral ${ }^{\circledR}$; and group 4 , OxOral ${ }^{\circledR}$ plus $\mathrm{Ca}(\mathrm{OH})_{2}$ paste. $\mathrm{Ca}(\mathrm{OH})_{2}$ medication pastes were prepared by mixing $0.5 \mathrm{~g}$ of $\mathrm{Ca}(\mathrm{OH})_{2}$ powder plus three drops of saline solution $(0.9 \% \mathrm{NaCl})$ or $\mathrm{OxOral}^{\circledR}$. All treated teeth were incubated for up to $18 \mathrm{~d}$.

2.4. Evaluation of Bacterial Growth. For E. faecalis growth evaluation, aliquots of $100 \mu \mathrm{L}$ were taken at days $1,6,12$, and 18 post-treatment, serially diluted, and plated onto BHI-supplemented agar using a glass spreader. Next, plates were incubated at $37^{\circ} \mathrm{C}$ for $24 \mathrm{~h}$, and $\mathrm{CFU} / \mathrm{mL}$ were calculated; all measurements were performed in triplicate.

2.5. Measurement of $\mathrm{pH}$ Variation. For $\mathrm{pH}$ measurements, 60 tubes $(15 \mathrm{~mL})$ containing $2 \mathrm{~mL}$ of BHI-supplemented broth were inoculated with $10 \mu \mathrm{L}$ of E. faecalis cells at $\sim 5$ $\log _{10} \mathrm{CFU} / \mathrm{mL}$ at $37^{\circ} \mathrm{C}$ for $24 \mathrm{~h}$. Tubes were then randomly divided into four groups and $9 \mathrm{~mL}$ of the different treatments were added. $\mathrm{pH}$ values were measured at days 1,6 , 12 , and 18 post-treatment, by a digital pH meter (Corning ${ }^{\circledR}$, Model 313; NY, USA) calibrated with buffer solutions (J.T.Baker-Avantor Performance Materials, S.A. de C.V, Mexico City, Mexico; $\mathrm{pH}=4.00 ; \mathrm{pH}=7.00$; and $\mathrm{pH}=$ 10.00) before each experiment. After removing the specimens, the container was placed in an orbital shaker (Prendo, INO-650 M, Mexico City, Mexico) for $5 \mathrm{sec}$ before measuring. The room temperature during the test was $25^{\circ} \mathrm{C}$.

2.6. Statistical Analysis. Results were expressed as means \pm standard deviation (SD) of the response of three replicate determinations per treatment from three independent experiments. The significance level was assessed by the ANOVA and Tukey's tests $(p<0.05)$, using the SPSS statistics software version 22 .

\section{Results}

3.1. Evaluation of Antimicrobial Properties of OxOral ${ }^{\circledR}$ in the Root Canals. E. faecalis growth was determined at days 6, 12, and 18. One-way ANOVA test was performed, taking the bacterial growth $\left(\log _{10} \mathrm{CFU} / \mathrm{mL}\right)$ as the dependent variable and the treatment groups and the time as independent variables. The results show significant differences in the treatment groups and the time, with a $p=0.001$ and $p=0.012$, respectively.

Our results showed significant $(\mathrm{p}<0.05)$ antimicrobial activity in the root canals treated with saline solution plus $\mathrm{Ca}(\mathrm{OH})_{2}, \mathrm{OxOral}^{\circledR}$, and $\mathrm{OxOral}{ }^{\circledR}$ plus $\mathrm{Ca}(\mathrm{OH})_{2}$ at $24 \mathrm{~h}$ with $0.051 \pm 0.072, \quad 0.044 \pm 0.07$, and $0.000032 \pm 0.072 \log _{10}$ $\mathrm{CFU} / \mathrm{mL}$, respectively. In addition, a sustained inhibitory effect was observed in saline solution plus $\mathrm{Ca}(\mathrm{OH})_{2}$ and OxOral ${ }^{\circledR}$ until day 6 posttreatment. However, only the combination of OxOral ${ }^{\circledR}$ plus $\mathrm{Ca}(\mathrm{OH})_{2}$ maintained its inhibitory potential against E. faecalis after $18 \mathrm{~d}$ post-treatment, as compared with the other treatments $(p<0.05)$, whereas saline solution showed a progressive increase in bacterial growth from $4.55 \pm 0.071 \log 10 \mathrm{CFU} / \mathrm{mL}$ (day 0 post-treatment) to $10.05 \pm 0.075$ (day 18 post-treatment), as expected(Table 1).

3.2. $\mathrm{pH}$ Measurements in the Treated Root Canals. The $\mathrm{pH}$ variation of the different treatments at days $0,1,6,12$, and 18 was also evaluated. One-way ANOVA test was performed, where the test variable was $\mathrm{pH}$ in function of the treatment groups and time. We observed a statistically significant $(\mathrm{p}<0.05)$ difference only in the treatment group but no difference was observed with regard to time $(p>0.05)$.

$\mathrm{pH}$ measurements in the root canals treated with saline solution and $\mathrm{OxOral}^{\circledR}$ showed neutral $\mathrm{pH}$ maintenance from day 0 (baseline) with $6.25 \pm 0.075$ and $7.003 \pm 0.321$ until day 18 post-treatment with $7.41 \pm 0.291$ and $7.456 \pm 0.196$, respectively, whereas root canals treated with saline solution plus $\mathrm{Ca}(\mathrm{OH})_{2}$ and $\mathrm{OxOral}{ }^{\circledR}$ plus $\mathrm{Ca}(\mathrm{OH})_{2}$ showed an alkaline $\mathrm{pH}$ from day 0 (baseline) with $12.149 \pm 0.021$ and $12.22 \pm 0.033$ until day 18 with $12.522 \pm 0.02$ and $12.586 \pm$ 0.083 , respectively. We did not observe statistical differences in $\mathrm{pH}$ values between these treatment groups (Table 2).

\subsection{Consistency of $\mathrm{OxOral}^{\circledR}$ plus $\mathrm{Ca}(\mathrm{OH})_{2}$ Combination.} Figure 1 shows a comparison of the macroscopic characteristics of the combination of saline solution plus $\mathrm{Ca}(\mathrm{OH})_{2}$ and OxOral ${ }^{\circledR}$ plus $\mathrm{Ca}(\mathrm{OH})_{2}$, where we observe a higher solubility and pasty consistencies compared with the traditional combination.

\section{Discussion}

One of the requirements of an endodontic root canal sealer is that it should not be cytotoxic and immunologically compatible with peripheral tissue. Therefore, a specific root canal sealer biocompatibility and antimicrobial activity remain one of the major considerations for selecting an appropriate sealer for a dental restoration. $\mathrm{Ca}(\mathrm{OH})_{2}$ has been widely used since the 1920s for its biocompatibility, antimicrobial potential, and ftissue restoration support in endodontic therapies [30].

Hydroxyl ions are responsible for $\mathrm{Ca}(\mathrm{OH})_{2}$ antimicrobial activity.Therefore, the efficacy of any product varies according to the availability of these ions in solution, which in turn reflects the nature of the solvent used. Most existing commercial $\mathrm{Ca}(\mathrm{OH})_{2}$ use vehicles of water. However, other agents have recently been mixed with water, such as glycerin or polyethylene glycol (PEG) [17].

The $\mathrm{pH}$ values from using OxOral are similar to some commercial $\mathrm{Ca}(\mathrm{OH})_{2}$ products that use vehicles of water such as Calasept Plus ${ }^{\mathrm{TM}}$, Calcipulpe ${ }^{\mathrm{TM}}$, DT Temp ${ }^{\mathrm{TM}}$, Pulpdent $^{\mathrm{TM}}$, and Ultracal $\mathrm{XS}^{\mathrm{TM}}$ with $\mathrm{pH}$ values between 11.8 and $12.7[17,31]$. However, there are reports where the $\mathrm{pH}$ reaches up to 15.0 in $\mathrm{Ca}(\mathrm{OH})_{2}$ products, where a mixture of water with PEG is used, such as Calmix ${ }^{\mathrm{TM}}$ [32]. 
TABLE 1: Enterococcus faecalis growth in the presence of $0.9 \%$ sodium chloride, $0.9 \%$ sodium chloride plus calcium hydroxide, OxOral, and OxOral plus calcium hydroxide.

\begin{tabular}{|c|c|c|c|c|}
\hline \multirow{2}{*}{ Posttreatment time (days) } & \multicolumn{4}{|c|}{ Treatment groups $\left(\log _{10} \mathrm{CFU} / \mathrm{mL} \pm \mathrm{SD}^{*}\right)$} \\
\hline & $0.9 \% \mathrm{NaCl}$ & $0.9 \% \mathrm{NaCl}+\mathrm{Ca}(\mathrm{OH})_{2}$ & OxOral & OxOral $+\mathrm{Ca}(\mathrm{OH})_{2}$ \\
\hline 0 & $4.55 \pm 0.071$ & $4.47 \pm 0.07$ & $4.6 \pm 0.074$ & $4.443 \pm 0.068$ \\
\hline 1 & $8.02 \pm 0.069$ & $0.051 \pm 0.072$ & $0.044 \pm 0.07$ & $0.000032 \pm 0.072$ \\
\hline 6 & $10.01 \pm 0.07$ & $0.1 \pm 0.071$ & $0.402 \pm 0.071$ & $0.0000031 \pm 0.074$ \\
\hline 12 & $10.02 \pm 0.073$ & $1.201 \pm 0.074$ & $0.993 \pm 0.07$ & $0.00005 \pm 0.074$ \\
\hline 18 & $10.05 \pm 0.075$ & $2.021 \pm 0.071$ & $1.904 \pm 0.075$ & $0.00003 \pm 0.07$ \\
\hline
\end{tabular}

${ }^{*}$ The data represent mean \pm standard deviation of $\log _{10} \mathrm{CFU} / \mathrm{mL}$.

TABLE 2: $\mathrm{pH}$ values in the presence of $0.9 \%$ sodium chloride, $0.9 \%$ sodium chloride plus calcium hydroxide, OxOral, and OxOral plus calcium hydroxide.

\begin{tabular}{lcccc}
\hline Posttreatment time (days) & \multicolumn{4}{c}{ Treatment groups (mean pH $\left.\pm \mathrm{SD}^{*}\right)$} \\
\hline 0 & $0.9 \% \mathrm{NaCl}$ & $0.9 \% \mathrm{NaCl}+\mathrm{Ca}(\mathrm{OH})_{2}$ & $\mathrm{OxOral}$ & $\mathrm{OxOral}+\mathrm{Ca}(\mathrm{OH})_{2}$ \\
\hline 1 & $6.25 \pm 0.075$ & $12.149 \pm 0.021$ & $7.003 \pm 0.321$ & $12.22 \pm 0.033$ \\
6 & $6.606 \pm 0.092$ & $12.268 \pm 0.024$ & $7.048 \pm 0.4$ & $12.448 \pm 0.05$ \\
12 & $6.606 \pm 0.092$ & $12.268 \pm 0.02$ & $6.506 \pm 0.495$ & $12.448 \pm 0.05$ \\
18 & $6.606 \pm 0.09$ & $11.794 \pm 0.656$ & $7.456 \pm 0.196$ & $12.272 \pm 0.130$ \\
\hline
\end{tabular}

${ }^{*}$ The data represent mean \pm standard deviation of $\mathrm{pH}$ measurements.

There are previous studies, where the use of neutral $\mathrm{pH}$ solutions is reported as a vehicle for the root canal $\mathrm{Ca}(\mathrm{OH})_{2}$ pastes. For example, Tronstad et al. used a Ringer's solution $\left(0.125 \mathrm{M} \mathrm{NaCl}, 1.5 \mathrm{mM} \mathrm{CaCl}_{2}\right.$ dihydrate, and $5 \mathrm{mM} \mathrm{KCl}$; $\mathrm{pH}=7.3-7.4)$ combined with $\mathrm{Ca}(\mathrm{OH})_{2}$ and filled the root canal of green monkey teeth (Cercopithecus aethiops sabaeus), and they observed maintenance of alkalinity conditions with a $\mathrm{pH}=12.2$ after four weeks [33]. However, there are no reports on using ESS at neutral $\mathrm{pH}$ as a vehicle to prepare $\mathrm{Ca}(\mathrm{OH})_{2}$.

Some studies suggest that $\mathrm{Ca}(\mathrm{OH})_{2}$ is a slow-acting antimicrobial, which requires at least 24 hours to produce a bactericidal effect against Enterococci spp. Furthermore, $\mathrm{Ca}(\mathrm{OH})_{2}$ hydroxide hydrolyzes the lipid moiety of bacterial LPS, causing its biological inactivation, the desired effect to prevent an inflammatory reaction in the periapical tissue $[34,35]$.

For many years, different compounds have been evaluated for root canal disinfection, $\mathrm{Ca}(\mathrm{OH})_{2}$-based pastes being the most widely used.However, the permanence in time of these pastes is one of the main discrepancies between the authors, mainly in the cases of the teeth with pulp necrosis and periapical lesion $[36,37]$. Our study observed the intracanal permanence of the $\mathrm{Ca}(\mathrm{OH})_{2}$ plus saline solution or OxOral ${ }^{\circledR}$ pastes for up to $18 \mathrm{~d}$.

Root treatment consists of debriding and disinfecting the entire root canal system, which requires eliminating the pulp tissue and the microorganisms causing the infection, adopting instrumentation and chemical irrigation mechanisms, and subsequently a medication in the root canal between treatment sessions. The success of endodontic treatment depends on the removal of microbes from the root canals and avoidance of reinfection.

Paudel et al. found that $0.9 \% \mathrm{NaCl}$ was as effective as sequential use of $3 \% \mathrm{H}_{2} \mathrm{O}_{2}, 5.2 \% \mathrm{NaOCl}$, and $0.9 \% \mathrm{NaCl}$, although saline has no antibacterial activity [38]. In addition, it has been reported that the exposure and contact time during the irrigation of human root canals are crucial, since treatment with ozonized water, $2.5 \% \mathrm{NaOCl}, 2 \% \mathrm{CHX}$, and gaseous ozone for $20 \mathrm{~min}$ was not sufficient to inactivate $E$. faecalis [39]. Therefore, in our study we evaluated the antimicrobial activity of treatments from one to $18 \mathrm{~d}$ posttreatment.

With a significant amount of calcium carbonate, the $\mathrm{Ca}(\mathrm{OH})_{2}$ paste has a granular consistency due to its low solubility $\left(1.73 \mathrm{~g} / \mathrm{L}\right.$ at $\left.20{ }^{\circ} \mathrm{C}\right)$. One of the most interesting observations in the present study was the ease of removing the paste composed of $\mathrm{Ca}(\mathrm{OH})_{2}$ plus $\mathrm{OxOral}^{\circledR}$, unlike that composed of $\mathrm{Ca}(\mathrm{OH})_{2}$ plus saline solution. However, other studies are necessary to evaluate any physical-chemical changes.

On the other hand, reactive oxygen and chlorine species are derived during the electrolysis process to produce electrolyzed water and have been previously evaluated in endodontic treatment. In this regard, Zhou et al. reported that a plasma jet with or without helium flowing through $3 \%$ hydrogen peroxide effectively sterilized root canals infected with Enterococcus faecalis [40]. Another study conducted by Mihadi et al. assessed the cytocompatibility and antibacterial activity of different concentrations of CHX combined with $\mathrm{H}_{2} \mathrm{O}_{2}$ compared with the action of $5.25 \%$ and $2.5 \%$ 


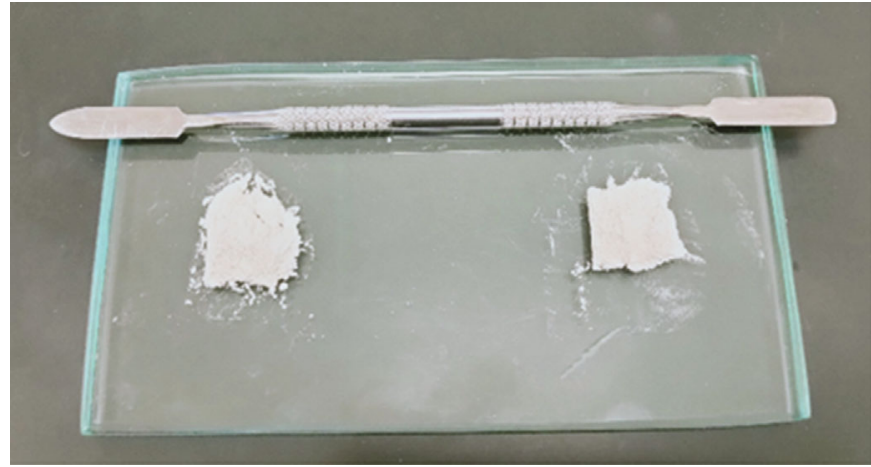

(a)

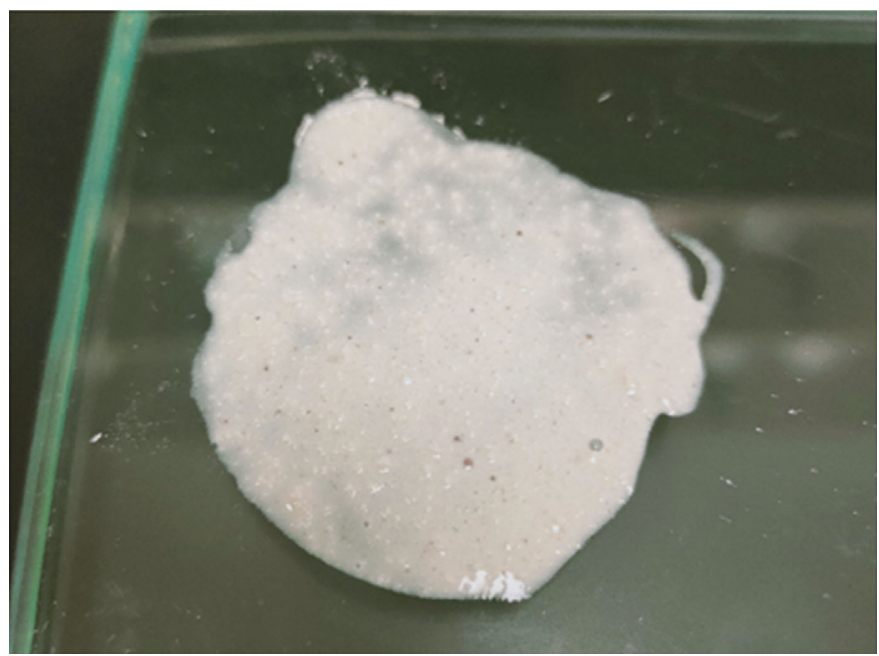

(c)

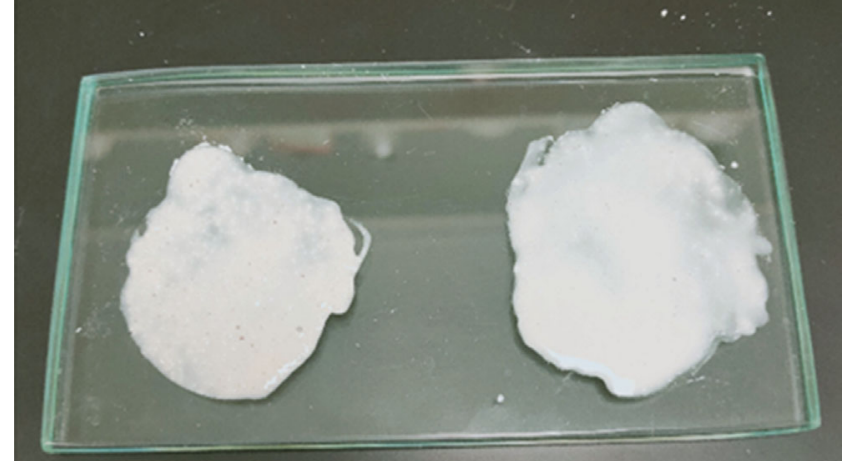

(b)

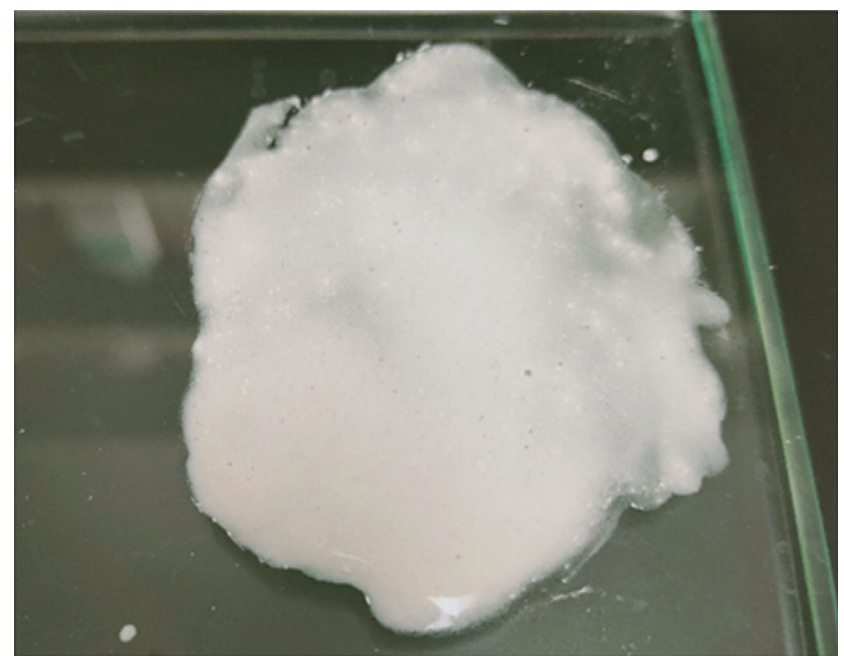

(d)

Figure 1: Comparison of the $\mathrm{Ca}(\mathrm{OH})_{2}$ solvents. (a) Comparison of the amount of $\mathrm{Ca}(\mathrm{OH})_{2}$ powder used; (b) comparison of the macroscopic characteristics of the combination of saline solution plus $\mathrm{Ca}(\mathrm{OH})_{2}$ (left) and OxOral plus $\mathrm{Ca}(\mathrm{OH})_{2}(\mathrm{right})$; (c) combination of saline solution plus $\mathrm{Ca}(\mathrm{OH})_{2}$; (d) combination of OxOral plus $\mathrm{Ca}(\mathrm{OH})_{2}$.

$\mathrm{NaOCl}$. All combinations of $\mathrm{CHX}$ and $\mathrm{H}_{2} \mathrm{O}_{2}$ except $0.1 \%$ CHX plus $3 \% \mathrm{H}_{2} \mathrm{O}_{2}$ were efficient irrigants against planktonic $E$. faecalis and had a better cytocompatibility with PDL cells than $5.25 \%$ and $2.5 \% \mathrm{NaOCl}$ [41].

Some studies have reported a significant antimicrobial activity of electrolyzed superoxidized water [42, 43]. Different antimicrobial broad-spectrum disinfectants are manufactured by Esteripharma ${ }^{\circledR}$, Mexico, SA of CV, each with different compositions and proposes. Velázquez-Meza et al. evaluated the antimicrobial activity based on superoxidized water called Estericide $\mathrm{Qx}^{\circledR}$ against 524 clinical bacterial isolates causing nosocomial infections, including Gramnegative (Escherichia coli and Pseudomonas aeruginosa beta-lactam resistant) and Gram-positive (Staphylococcus aureus and Streptococcus epidermidis methicillin-resistant, and Enterococcus faecium). The results showed that Estericide $\mathrm{Qx}^{\circledR}$ provides a broad-spectrum antibacterial activity mainly in Gram-negative [44]. Other studies, LucioSauceda et al., reported a significant anti- $H$. pylori activity of $\mathrm{OxOral}^{\circledR}$ by microdilution assays, and Rivera-Garcia et al. observed a significant antimicrobial activity against Listeria monocytogenes on eggshells $[18,22]$.
Landa-Solis et al. treated pure cultures of S. aureus, E. coli, $P$. aeruginosa, Salmonella typhi, and Candida albicans with Microcyn ${ }^{\circledR}$ and found it was active on all microorganisms tested [45]. In addition, Vorobjeva et al. reported that superoxidized solution was effective on spores, Gram-positive, and Gram-negative bacteria related to nosocomial infections [46].

According to many studies, chlorine and a high concentration of ORP in ESS seem to be responsible for its antimicrobial activity. Active chlorine compounds destroys the membranes of microorganisms. Other modes of chlorine action (e.g., decarboxylation of amino acids, reactions with nucleic acids, and unbalanced metabolism after the destruction of crucial enzymes) also have been proposed [20,47]. Studies suggest that $\mathrm{HOCl}$ is the most active of the chlorine compounds because $\mathrm{HOCl}$ penetrates cell membranes and produces hydroxyl radicals, which exert their antimicrobial activity through the oxidation of crucial metabolic systems. In addition, $\mathrm{OH}$ radicals, which are the most potent oxidizing agents, also have shown antimicrobial activity $[24,29,48]$.

The main characteristics of $\mathrm{Ca}(\mathrm{OH})_{2}$ are its limited solubility, high $\mathrm{pH}$, and use as a broad-spectrum antimicrobial 
agent. Despite the benefits and advantages of $\mathrm{Ca}(\mathrm{OH})_{2}$, its use is cumbersome. Proper handling and placement are challenging for the dentist. In addition, its removal from the canal is usually incomplete, with $20-45 \%$ residue on the canal wall, even after copious irrigation using saline, sodium hypochlorite, or EDTA. Residual $\mathrm{Ca}(\mathrm{OH})_{2}$ may shorten the setting time of zinc oxide-eugenol endodontic sealants. In particular, it may interfere with the sealing of a root filling and affect the quality of the treatment.

On the other hand, the potential of $\mathrm{Ca}(\mathrm{OH})_{2}$ to eliminate bacteria from the root canal has recently been challenged. Some in vitro studies have reported that dentin inactivates the antimicrobial activity of $\mathrm{Ca}(\mathrm{OH})_{2}$, and a clinical study reported an increase in bacterial growth after its application. Our findings agree with these studies since the combination of $\mathrm{Ca}(\mathrm{OH})_{2}$ plus saline solution showed an increase in bacterial growth of E. faecalis after day six of treatment. However, in the root canals treated with the combination of $\mathrm{Ca}(\mathrm{OH})_{2}$ plus $\mathrm{OxOral}{ }^{\circledR}$, we did not observe $E$. faecalis growth. Therefore, it is possible that OxOral ${ }^{\circledR}$ may have a synergistic effect with $\mathrm{Ca}(\mathrm{OH})_{2}$.

\section{Conclusions}

Taken together, the results of the present study demonstrated that the combination of $\mathrm{OxOral}{ }^{\circledR}$ plus $\mathrm{Ca}(\mathrm{OH})_{2}$ showed a significant antimicrobial activity and solubility of $\mathrm{Ca}(\mathrm{OH})_{2}$, prolonging the alkaline $\mathrm{pH}$ conditions. Our results open the possibility for further research on the use of OxOral ${ }^{\circledR}$ for sealing root canals, during endodontic treatment.

\section{Data Availability}

The data used to support the findings of this study are available from the corresponding author upon request.

\section{Conflicts of Interest}

The authors declare that there is no conflict of interest regarding the publication of this article.

\section{Acknowledgments}

This work was supported by Esteripharma ${ }^{\circledR}$ Mexico, SA de $\mathrm{CV}$, and Consejo Nacional de Ciencia y Tecnología to MGR (CONACYT-México; grant number 251475; 2016). The authors would like to thank the Integral Dentistry Unit and Specialties of Center for Research and Development in Health Sciences at Autonomous University of Nuevo Leon for supporting the development of this study.

\section{References}

[1] S. Cushley, H. F. Duncan, M. J. Lappin et al., "Pulpotomy for mature carious teeth with symptoms of irreversible pulpitis: a systematic review," Journal of Dentistry, vol. 88, article 103158, 2019.

[2] T. Morotomi, A. Washio, and C. Kitamura, "Current and future options for dental pulp therapy," Japanese Dental Science Review, vol. 55, no. 1, pp. 5-11, 2019.
[3] B.-N. Lee, J.-W. Moon, H.-S. Chang, I.-N. Hwang, W.-M. Oh, and Y.-C. Hwang, "A review of the regenerative endodontic treatment procedure," Restorative Dentistry \& Endodontics, vol. 40, no. 3, pp. 179-187, 2015.

[4] N. Yazdanpanahi, A. Behzadi, and M. Zare Jahromi, "Longterm $\mathrm{pH}$ alterations in the periradicular area following the application of calcium hydroxide and MTA," Journal of Dentistry, vol. 22, no. 2, pp. 90-95, 2021.

[5] C. Estrela, R. Holland, C. R. . A. Estrela, A. H. G. Alencar, M. D. Sousa-Neto, and J. D. Pécora, "Characterization of successful root canal treatment," Brazilian Dental Journal, vol. 25, no. 1, pp. 3-11, 2014.

[6] Z. Xie, Z. Shen, P. Zhan et al., "Functional dental pulp regeneration: basic research and clinical translation," International Journal of Molecular Sciences, vol. 22, no. 16, article 8991, 2021.

[7] S. Desai and N. Chandler, "Calcium hydroxide-based root canal sealers: a review," Journal of Endodontics, vol. 35, no. 4, pp. 475-480, 2009.

[8] S. Singh, B. Srivastava, K. Gupta, N. Gupta, S. Singh, and S. Singh, "Comparative evaluation of antifungal efficacy of five root canal sealers against clinical isolates of candida albicans: a microbiological study," International Journal of Clinical Pediatric Dentistry, vol. 13, no. 2, pp. 119-123, 2020.

[9] N. Arandi, "Calcium hydroxide liners: a literature review," Clinical, Cosmetic and Investigational Dentistry, vol. Volume 9, pp. 67-72, 2017.

[10] M. Cvek, I. Mejare, and J. O. Andreasen, "Conservative endodontic treatment of teeth fractured in the middle or apical part of the root," Dental Traumatology, vol. 20, no. 5, pp. 261-269, 2004.

[11] D. Ørstavik, "Root canal disinfection: a review of concepts and recent developments," Australian Endodontic Journal, vol. 29, no. 2, pp. 70-74, 2003.

[12] B. Athanassiadis, P. V. Abbott, and L. J. Walsh, "The use of calcium hydroxide, antibiotics and biocides as antimicrobial medicaments in endodontics," Australian Dental Journal, vol. 52, 1 Suppl, pp. S64-S82, 2007.

[13] C. Estrela, D. . A. Decurcio, G. Rossi-Fedele, J. A. Silva, O. A. Guedes, and Á. H. Borges, "Root perforations: a review of diagnosis, prognosis and materials," Brazilian Oral Research, vol. 32, suppl 1, p. e73, 2018.

[14] F. Alghamdi and M. Shakir, "The influence of Enterococcus faecalis as a dental root canal pathogen on endodontic treatment: a systematic review," Cureus, vol. 12, no. 3, article e7257, 2020.

[15] N. A. Vatkar, V. Hegde, and S. Sathe, "Vitality of Enterococcus faecalis inside dentinal tubules after five root canal disinfection methods," Journal of Conservative Dentistry, vol. 19, no. 5, pp. 445-449, 2016.

[16] S. Kranz, A. Guellmar, F. Braeutigam et al., "Antibacterial effect of endodontic disinfections on Enterococcus faecalis in dental root canals-an in-vitro model study," Materials, vol. 14, no. 9, p. 2427, 2021.

[17] B. Athanassiadis and L. J. Walsh, "Aspects of solvent chemistry for calcium hydroxide medicaments," Materials, vol. 10, no. 10, p. 1219, 2017.

[18] D. G. Lucio-Sauceda, V. H. Urrutia-Baca, R. Gomez-Flores, M. A. De La Garza-Ramos, P. Tamez-Guerra, and A. Orozco-Flores, "Antimicrobial and anti-biofilm effect of an electrolyzed superoxidized solution at neutral-pH against 
Helicobacter pylori," BioMed Research International, vol. 2019, Article ID 6154867, 9 pages, 2019.

[19] B. Ayebah and Y.-C. Hung, "Electrolyzed water and its corrosiveness on various surface materials commonly found in food processing facilities," Journal of Food Process Engineering, vol. 28 , no. 3, pp. 247-264, 2005.

[20] A. D. Ogunniyi, C. E. Dandie, S. Ferro et al., "Comparative antibacterial activities of neutral electrolyzed oxidizing water and other chlorine-based sanitizers," Scientific Reports, vol. 9, no. 1, p. 19955, 2019.

[21] H. S. You, A. Fadriquela, M. E. J. Sajo et al., "Wound healing effect of slightly acidic electrolyzed water on cutaneous wounds in hairless mice via immune-redox modulation," Biological \& Pharmaceutical Bulletin, vol. 40, no. 9, pp. 14231431, 2017.

[22] A. Rivera-Garcia, L. Santos-Ferro, J. C. Ramirez-Orejel et al., "The effect of neutral electrolyzed water as a disinfectant of eggshells artificially contaminated withListeria monocytogenes," Food Science \& Nutrition, vol. 7, no. 7, pp. 22522260, 2019.

[23] M. Kaczmarek, S. V. Avery, and I. Singleton, "Microbes associated with fresh produce: Sources, types and methods to reduce spoilage and contamination," Advances in Applied Microbiology, vol. 107, pp. 29-82, 2019.

[24] P. Yan, E. B. Daliri, and D. H. Oh, "New clinical applications of electrolyzed water: a review," Microorganisms, vol. 9, no. 1, p. 136, 2021.

[25] R. Zan, G. Kutlu, I. Hubbezoglu, Z. Sumer, T. Tunc, and Z. Mutlu, "Bactericidal effects of various irrigation solutions against Staphylococcus aureus in human root canal," Journal of Istanbul University Faculty of Dentistry, vol. 49, no. 1, pp. 19-26, 2015.

[26] A. Herrera Saucedo, M. A. Corona Guerra, F. J. Vara Padilla, D. H. Gutiérrez Valdez, and S. L. Alavez Rebollo, "Comparación de la eficacia de los irrigantes OxOral ${ }^{\circledR}$ y $\mathrm{NaOCl}$ en la eliminación de Enterococcus faecalis," Revista Odontológica Mexicana, vol. 21, no. 4, pp. 241-244, 2017.

[27] M. E. R. Briones, D. Silva-Herzog Flores, A. M. González Amaro, and R. O. Rodríguez, "Comparative assessment of the antimicrobial capacity of an electrolyzed superoxide solution of neutral $\mathrm{pH}$ and a hydrogen peroxide-based solution," Revista de la Asociación Dental Mexicana, vol. 70, no. 4, pp. 183-189, 2013.

[28] X. Cheng, Y. Tian, C. Zhao et al., "Bactericidal Effect of Strong Acid Electrolyzed Water against Flow Enterococcus faecalis Biofilms," Journal of Endodontics, vol. 42, no. 7, pp. 1120$1125,2016$.

[29] T. Okamura, M. Tamura, H. Suguro et al., "Bactericidal and cytotoxic effects of acid-electrolyzed functional water," Journal of Oral Science, vol. 61, no. 4, pp. 512-515, 2019.

[30] D. A. Fonseca, A. B. Paula, C. M. Marto et al., "Biocompatibility of root canal sealers: a systematic review of in vitro and in vivo studies," Materials, vol. 12, no. 24, p. 4113, 2019.

[31] B. Athanassiadis, P. V. Abbott, N. George, and L. J. Walsh, "An in vitro study of the antimicrobial activity of some endodontic medicaments against Enteroccus faecalis biofilms," Australian Dental Journal, vol. 55, no. 2, pp. 150-155, 2010.

[32] Y.-Y. Teoh, B. Athanassiadis, and L. J. Walsh, "The influence of aqueous and PEG 400 solvent vehicles on hydroxyl ion release from calcium hydroxide medicaments," International Dentistry, vol. 11, pp. 42-50, 2016.

[33] L. Tronstad, J. O. Andreasen, G. Hasselgren, L. Kristerson, and I. Riis, " $\mathrm{pH}$ changes in dental tissues after root canal filling with calcium hydroxide," Journal of Endodontics, vol. 7, no. 1, pp. 17-21, 1981.

[34] K. Safavi and F. Nichols, "Effect of calcium hydroxide on bacterial lipopolysaccharide," Journal of Endodontics, vol. 19, no. 2, pp. 76-78, 1993.

[35] A. Adl, M. Motamedifar, M. S. Shams, and A. Mirzaie, "Clinical investigation of the effect of calcium hydroxide intracanal dressing on bacterial lipopolysaccharide reduction from infected root canals," Australian Endodontic Journal, vol. 41, no. 1, pp. 12-16, 2015.

[36] Z. Mohammadi and P. M. H. Dummer, "Properties and applications of calcium hydroxide in endodontics and dental traumatology," International Endodontic Journal, vol. 44, no. 8, pp. 697-730, 2011.

[37] L. R. G. Fava and W. P. Saunders, "Calcium hydroxide pastes: classification and clinical indications," International Endodontic Journal, vol. 32, no. 4, pp. 257-282, 1999.

[38] K. R. Paudel, A. Jaiswal, U. Parajuli, and M. Bajracharya, "Different pharmacological solutions in intracanal irrigation," Nepal Medical College Journal, vol. 13, no. 2, pp. 111-114, 2011.

[39] C. Estrela, C. R. A. Estrela, D. A. Decurcio, A. C. B. Hollanda, and J. A. Silva, "Antimicrobial efficacy of ozonated water, gaseous ozone, sodium hypochlorite and chlorhexidine in infected human root canals," International Endodontic Journal, vol. 40, no. 2, pp. 85-93, 2007.

[40] X.-C. Zhou, Y.-L. Li, D.-X. Liu, Y.-G. Cao, and X.-P. Lu, "Bactericidal effect of plasma jet with helium flowing through $3 \%$ hydrogen peroxide against Enterococcus faecalis," Experimental and Therapeutic Medicine, vol. 12, no. 5, pp. 3073-3077, 2016.

[41] H. Mirhadi, A. Abbaszadegan, M. A. Ranjbar et al., "Antibacterial and toxic effect of hydrogen peroxide combined with different concentrations of chlorhexidine in comparison with sodium hypochlorite," Journal of Dentistry, vol. 16, no. 4, pp. 349-355, 2015.

[42] M. Gunaydin, S. Esen, A. Karadag et al., "In vitro antimicrobial activity of Medilox ${ }^{\circledR}$ super-oxidized water," Annals of Clinical Microbiology and Antimicrobials, vol. 13, no. 1, p. 29, 2014.

[43] S. H. Lee and B. K. Choi, "Antibacterial effect of electrolyzed water on oral bacteria," Journal of Microbiology, vol. 44, no. 4, pp. 417-422, 2006.

[44] M. E. Velazquez-Meza, M. Hernández-Salgado, and M. A. Sánchez-Alemán, "Evaluation of the antimicrobial activity of a super oxidized solution in clinical isolates," Microbial Drug Resistance, vol. 21, no. 4, pp. 367-372, 2015.

[45] C. Landa-Solis, D. González-Espinosa, B. Guzmán-Soriano et al., "Microcyn ${ }^{\mathrm{tm}}$ : a novel super-oxidized water with neutral $\mathrm{pH}$ and disinfectant activity," Journal of Hospital Infection, vol. 61, no. 4, pp. 291-299, 2005.

[46] N. V. Vorobjeva, L. I. Vorobjeva, and E. Y. Khodjaev, "The bactericidal effects of electrolyzed oxidizing water on bacterial strains involved in hospital infections," Artificial Organs, vol. 28, no. 6, pp. 590-592, 2004. 
[47] D. Hricova, R. Stephan, and C. Zweifel, "Electrolyzed water and its application in the food industry," Journal of Food Protection, vol. 71, no. 9, pp. 1934-1947, 2008.

[48] X. Zeng, W. Tang, G. Ye et al., "Studies on disinfection mechanism of electrolyzed oxidizing water on E. coli and Staphylococcus aureus," Journal of Food Science, vol. 75, no. 5, pp. M253-M260, 2010. 